\title{
Effect of biofertilizer obtained by anaerobic digestion of cassava effluent on the development of crambe plants
}

\author{
Andressa C. Neves ${ }^{1}$, Camila N. Bergamini ${ }^{2}$, Rafaela de O. Leonardo ${ }^{2}$, \\ Manoel P. Gonçalves ${ }^{3}$, Dilcemara C. Zenatti ${ }^{2}$ Eliane Hermes $^{2}$ \\ ${ }^{1}$ Universidade Estadual do Oeste do Paraná/Programa de Pós-Graduação em Engenharia de Energia na Agricultura. Cascavel, PR. E-mail: \\ andressacarolineves@gmail.com \\ ${ }^{2}$ Universidade Federal do Paraná/Setor Palotina/Departamento de Engenharias e Exatas. Palotina, PR. E-mail: camilanayaraber@gmail.com; \\ rafaela.oliveiraleonardo@gmail.com; dilzenatti@gmail.com; elianehermes@yahoo.com.br (Corresponding author) \\ ${ }^{3}$ Universidade Federal do Paraná/Setor Palotina/Departamento de Ciências Agronômicas. Palotina, PR. E-mail: manoel.penachio@gmail.com
}

Key words:

organic fertilizer

utilization of waste

oil content

\begin{abstract}
A B S T R A C T
This study aimed to evaluate the effect of applying increasing doses of biofertilizer obtained by the anaerobic digestion of cassava effluent on the development of crambe plants. The experiment was conducted in a protected environment at the Federal University of Paraná (UFPR), Palotina Sector, between April and August 2015. A completely randomized design was used, and five different treatments with the following doses were applied in five replicates: $0,40,80,120$, and $160 \mathrm{~kg} \mathrm{ha}^{-1}$ of $\mathrm{K}_{2} \mathrm{O}$. The following parameters related to plant development were evaluated: final height, stem diameter, number of branches, dry shoot and root biomass, mass of the grains, and oil content. The $160 \mathrm{~kg} \mathrm{~K}_{2} \mathrm{O} \mathrm{ha}^{-1}$ dose was found to have the best influence on the plant development, because all the measured parameters reached their highest values at this dose, except for oil content, which attained the highest percentage in the case of the control treatment $\left(0 \mathrm{~kg} \mathrm{ha}^{-1}\right.$ of $\left.\mathrm{K}_{2} \mathrm{O}\right)$. This study proved that the biofertilizer obtained by anaerobic digestion of cassava effluent can be used as an alternative to regular fertilizers in cultivating crambe.
\end{abstract}

\section{Palavras-chave:}

adubação orgânica aproveitamento de resíduo teor de óleo

\section{Efeito de biofertilizante obtido da digestão anaeróbia de manipueira no desenvolvimento de plantas de crambe}

\begin{abstract}
R E S U M O
Objetivou-se, neste estudo, avaliar o uso de doses crescentes de biofertilizante obtido da digestão anaeróbia da manipueira no desenvolvimento de plantas de crambe. O experimento foi conduzido em ambiente protegido na Universidade Federal do Paraná (UFPR) - Setor Palotina, no período de abril a agosto de 2015. Utilizou-se um delineamento inteiramente casualisado, com cinco tratamentos compostos das seguintes doses foram aplicados em cinco repetições: 0, 40, 80, 120 e $160 \mathrm{~kg} \mathrm{ha}^{-1} \mathrm{de}_{2} \mathrm{O}$. Os seguintes parâmetros de desenvolvimento das plantas foram avaliados: altura final, diâmetro de caule, número de ramificações, biomassa seca da parte aérea e radicular, massa dos grãos e teor de óleo. A dose de 160 $\mathrm{kg} \mathrm{ha}^{-1}$ de $\mathrm{K}_{2} \mathrm{O}$ proporcionou melhor desenvolvimento das plantas atingindo os maiores valores em todas as variáveis, exceto para o teor de óleo, que obteve a porcentagem mais elevada para o tratamento testemunha $\left(0 \mathrm{~kg} \mathrm{ha}^{-1} \mathrm{de}_{2} \mathrm{O}\right)$. Este estudo demonstrou que o uso do biofertilizante obtido da digestão anaeróbia da manipueira serviu como fonte de adubação, passível de ser utilizado alternativamente na cultura do crambe.
\end{abstract}




\section{INTRODUCTION}

Effluents from anaerobic digestion can be utilized as fertilizers, owing to their high nutrient content. However, when these effluents are used untreated and applied to the ground, the high organic content in the crude residue competes for oxygen with the soil microorganisms and plants; hence, the efficiency of the effluents decreases (Ribas et al., 2010).

Cassava effluents cause serious environmental damage when discharged in watercourses. However, they can be efficiently used in agriculture to promote soil fertility and treat nutritional deficiency, because they are rabidly absorbed by plants (Nobile \& Mussi, 2013; Magalhães et al., 2014).

Dantas et al. (2015) evaluated the growth of sunflower using cassava effluent and found that the factors related to plant growth increased with greater applied doses of this effluent. Magalhães et al. (2014) investigated the use of the same effluent to promote the development of corn, confirming that it can be used as a source of fertilizer whose efficiency depends on the use of appropriate doses of the residue.

Crambe (Crambe abyssinica Hochst) is a species of the Brassicaceae family with high productivity (1000-2000 $\left.\mathrm{kg} \mathrm{ha}^{-1}\right)$ and high oil production capacity (36-38\%) in biodiesel manufacturing (Feroldi et al., 2012; Fundação MS, 2015). In Brazil, it can be cultivated as an off-season crop in grain producing regions, and it has been widely used in the crop rotation systems in the Midwest (Alves et al., 2016).

Studies on the fertility of the crambe crop are still limited; therefore, there are no specific recommendations available on the subject. However, studies that explore the effect of reusing effluents with great nutritional value on the growth of this crop are fundamental. Thus, the objective of this study was to evaluate the influence of increasing doses of biofertilizer obtained by the anaerobic digestion of cassava effluent on the development of crambe plants.

\section{Material AND Methods}

The experiment was conducted in the period from April to August 2015 in a heated greenhouse at $25 \pm 5{ }^{\circ} \mathrm{C}$ with a controlled humidity ranging from 70 to $100 \%$ at the Federal University of Paraná (UFPR) - Palotina Sector $\left(24^{\circ} 17^{\prime} 02^{\prime \prime} \mathrm{S}\right.$ and $53^{\circ} 50^{\prime} 24^{\prime \prime} \mathrm{W}$ ).

The soil used was collected from a rural property in the city of Palotina, PR. The selected soil was classified as Soil Type 3 with a clayey texture and clay content greater than or equal to $35 \%$ (EMBRAPA, 2013). The soil characterization was performed before the incorporation of the biofertilizer from anaerobic digestion (Table 1).

The cassava effluent used in this study was collected from an agribusiness in the city of Terra Roxa-PR. It was fed to a continuous anaerobic digester with a useful volume of $15 \mathrm{~L}$ installed in the laboratory of Analytical Chemistry and Environmental Analyses of UFPR- Palotina Sector, and a 15 days hydraulic detention time was applied. Further, the biofertilizer was characterized according to the APHA methodologies (APHA, 1995) (Table 2).
Table 1. Physical and chemical characteristics of red eutrophic latosol prior to the application of biofertilizer

\begin{tabular}{lcr}
\hline \multicolumn{1}{c}{ Parameter } & Unit & Value \\
Sand & $\mathrm{g} \mathrm{kg}^{-1}$ & 187.50 \\
Silt & $\mathrm{g} \mathrm{kg}^{-1}$ & 175.00 \\
Clay & $\mathrm{g} \mathrm{kg}^{-1}$ & 637.50 \\
$\mathrm{pH}$ in water & - & 5.50 \\
Calcium & $\mathrm{cmol}_{\mathrm{c}} \mathrm{dm}^{-3}$ & 5.39 \\
Magnesium & $\mathrm{cmol}_{\mathrm{c}} \mathrm{dm}^{-3}$ & 0.87 \\
Potassium & $\mathrm{cmol}_{\mathrm{c}} \mathrm{dm}^{-3}$ & 0.51 \\
Aluminum & $\mathrm{cmol}_{\mathrm{c}} \mathrm{dm}^{-3}$ & 0.00 \\
H + Aluminum & $\mathrm{cmol}_{\mathrm{c}} \mathrm{dm}^{-3}$ & 4.28 \\
CTC & $\mathrm{cmol}_{\mathrm{c}} \mathrm{dm}^{-3}$ & 11.05 \\
Carbon & $\mathrm{g} \mathrm{dm}^{-3}$ & 13.65 \\
Organic Matter & $\mathrm{g} \mathrm{dm}^{-3}$ & 23.48 \\
Phosphorus & $\mathrm{mg} \mathrm{dm}^{-3}$ & 8.93 \\
\hline
\end{tabular}

Table 2. Physical and chemical characteristics of the biofertilizer obtained by anaerobic digestion of cassava effluent

\begin{tabular}{lcc}
\hline \multicolumn{1}{c}{ Parameter } & Unit & Value \\
$\mathrm{pH}$ & - & 4.88 \\
Electrical conductivity & $\mathrm{dS} \mathrm{m}^{-1}$ & 3.29 \\
Total Solids & $\mathrm{mg} \mathrm{L}^{-1}$ & 5.111 \\
Chemical oxygen demand (COD) & $\mathrm{mg} \mathrm{L}^{-1}$ & 21.115 \\
Nitrogen & $\mathrm{mg} \mathrm{L}^{-1}$ & 900 \\
Phosphorus & $\mathrm{mg} \mathrm{L}^{-1}$ & 110 \\
Potassium & $\mathrm{mg} \mathrm{L}^{-1}$ & 360 \\
Sodium & $\mathrm{mg} \mathrm{L}^{-1}$ & 156 \\
\hline
\end{tabular}

A completely randomized design was used in the study. In addition, five doses $\left(0,40,80,120\right.$, and $160 \mathrm{~kg} \mathrm{ha}^{-1}$ of $\left.\mathrm{K}_{2} \mathrm{O}\right)$ of the biofertilizer treatment equivalent to $0,369,738,1107$, and $1476 \mathrm{~mL}$ biofertilizer per pot, respectively, were tested, and each was applied in five replicates, resulting in a total of 25 applications in 8 -L pots.

The seeds of crambe crop "FMS Brilhante" were provided by the MS Foundation, located in Maracaju-MS. They were sown in April 2015 at a $2 \mathrm{~cm}$ soil depth with a rate of 12 seeds per pot. Thinning was carried out 10 days after seeding, leaving 6 plants per pot, which resulted in the occurrence of the first flower buds at approximately 37 days after seeding (DAS) and blossoming at 51 DAS.

Final height, stem diameter, number of branches, dry mass of shoot and root, mass of the grains, and oil content were monitored in order to assess the development of the plants.

At 50 DAS, the stem diameter was evaluated with a digital caliper (Digimess 100,174 BL PLUS), and the number of branches per plant was determined by counting them on the main stem.

At the end of the experiment, the dry biomass production was evaluated. Therefore, plants were cut, separated in shoot and root, wrapped in paper bags, and dried in a forced air circulation oven at $60{ }^{\circ} \mathrm{C}$ for $24 \mathrm{~h}$ following the method of Nakagawa (1999). Next, they were weighed using an analytical scale (Radwag model 220/C/2).

The same procedures mentioned above were used for the drying of the biomass of the grains, and the yield was quantified, weighing each treatment and its quantification in all plants. Further, oil content was measured using the AOCS method BC. 3.11 (AOCS, 1998).

Analysis of variance was conducted on all data obtained, except for oil content, at a significance level of 0.05 using the 
Sisvar software version 5.3 (Ferreira, 2010). Regression analyses were performed when the response variable was significant, using mathematical models at 0.01 level of significance.

\section{Results AND Discussion}

According to the analysis of variance (ANOVA), applying an increasing dose of biofertilizer obtained by anaerobic digestion of cassava effluent had a significant influence on all evaluated parameters, except for the final height and dry mass of the roots (Table 3 ).

There was a slight difference between the heights of the plants that received $40 \mathrm{~kg} \mathrm{ha}^{-1}$ and those that received $160 \mathrm{~kg} \mathrm{ha}^{-1}$ of $\mathrm{K}_{2} \mathrm{O}$ with heights of 79.24 and $80.87 \mathrm{~cm}$, respectively. At 80 and $120 \mathrm{~kg} \mathrm{~K}_{2} \mathrm{O} \mathrm{ha}^{-1}$, the growth was slightly lower with averages of 70.40 and $72.90 \mathrm{~cm}$, respectively, while for the control treatment the average height was $60.36 \mathrm{~cm}$.

Similarly, Pitol et al. (2010) did not observe statistical differences between the results while assessing the effects of the following doses: 100,200 , and $300 \mathrm{~kg} \mathrm{ha}^{-1}$ of NPK 7-24-24 as well as the control treatment on the cultivation of crambe. Moreover, Silva Júnior et al. (2012) did not find any positive correlation between the use of cassava effluent and the height of banana plants; however, there was an increase in the productivity.

The results of the dry biomass of the roots were similar for the doses: 40, 80, and $160 \mathrm{~kg} \mathrm{ha}^{-1}$ of $\mathrm{K}_{2} \mathrm{O}$, with $0.21,0.21$, and $0.24 \mathrm{~g} \mathrm{plant}^{-1}$, respectively. Furthermore, the average value of the root dry biomass at $120 \mathrm{~kg} \mathrm{ha}^{-1}$ of $\mathrm{K}_{2} \mathrm{O}$ was $0.15 \mathrm{~g} \mathrm{plant}^{-1}$, which is slightly low, and $0.05 \mathrm{~g} \mathrm{plant}^{-1}$ at the control treatment. Prates et al. (2014) reported a significant increase (2.93 g plant $^{-1}$ at a dose of $\left.8 \mathrm{tha}^{-1}\right)$ in the root dry biomass of crambe as a result of applying high doses of castor cake, which confirms the high nutrient level required to cultivate this plant, corroborating with the results of this study.

The doses of biofertilizer caused a great difference in stem diameter (Figure 1A), number of branches (Figure 1B), dry biomass of shoot (Figure 1C) and root (Figure 1D) in comparison to control treatment, confirming the absorption of nutrients by plants favoring their growth.

The interactions between nutrients are estimated through the changes in the growth and nutrient concentrations in the plants. These interactions may be synergistic or antagonistic depending on the change in the plants' development (Fageria, 2001).

Nobile \& Mussi (2013) evaluated the stem diameter and number of branches of crambe using bovine biofertilizer. Good results were achieved at $6 \mathrm{~m}^{3} \mathrm{ha}^{-1}$ (7.0 $\mathrm{mm}$ and 24 branches), indicating that the plants responded to that treatment better than the treatments used in this study.
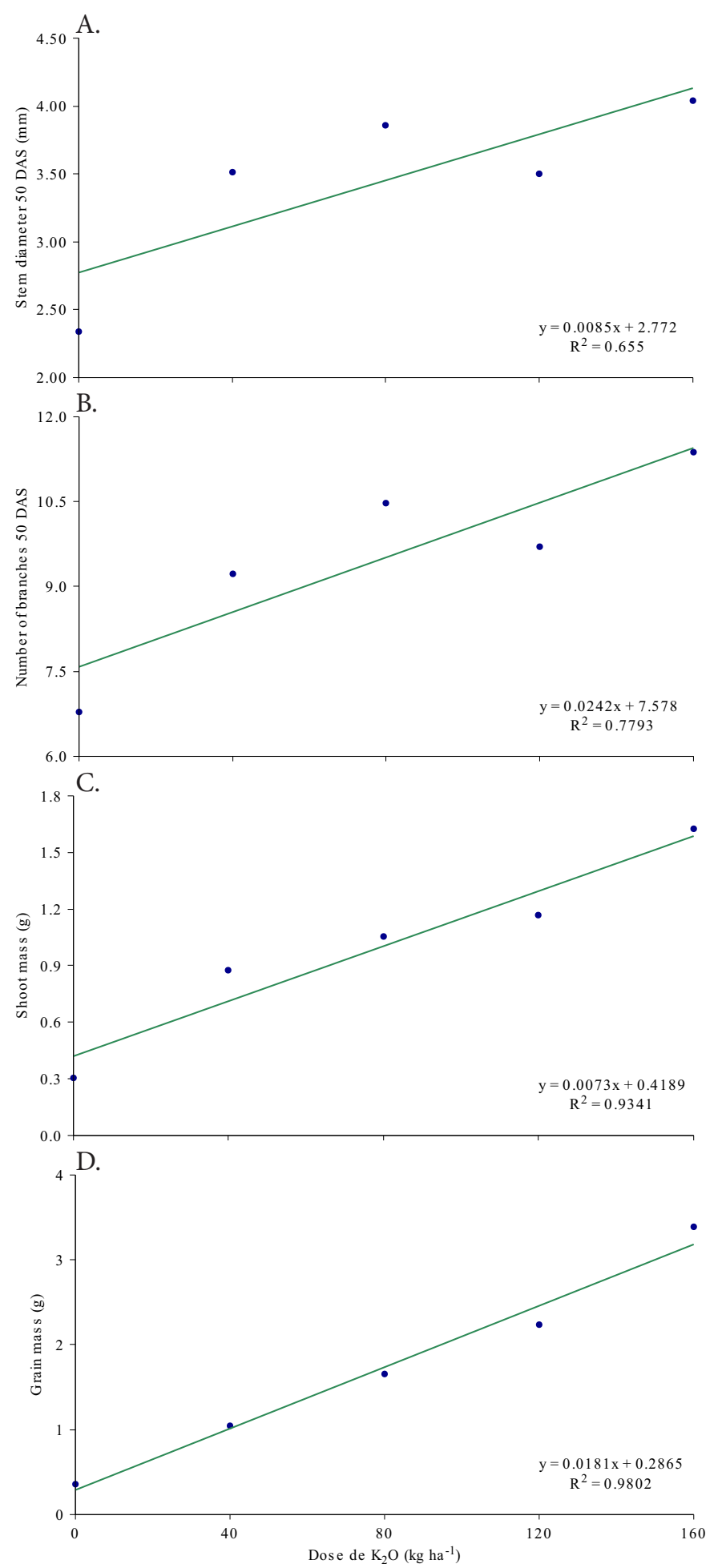

Figure 1. Stem diameter (A), number of branches at 50 DAS (B), shoot dry biomass (C), and mass of grains (D) as a function of the biofertilizer application doses

Table 3. Summary of the analyses of variance for final height, stem diameter, number of branches, dry biomass of shoot, root and the grains

\begin{tabular}{|c|c|c|c|c|c|c|c|}
\hline \multirow[b]{2}{*}{ SV } & \multirow[b]{2}{*}{ DF } & \multicolumn{6}{|c|}{ Mean square } \\
\hline & & Height & $\begin{array}{c}\text { Stem diameter } \\
50 \text { DAS }\end{array}$ & $\begin{array}{c}N^{\circ} \text { of branches } \\
50 \text { DAS }\end{array}$ & Shoot mass & Root dry mass & Mass of grains \\
\hline Dose & 4 & $365^{\text {ns }}$ & $2.21^{\star}$ & $14.94^{*}$ & $1.15^{\star}$ & $0.03^{\text {ns }}$ & $6.72^{\star}$ \\
\hline Residue & 20 & 399 & 0.55 & 4.63 & 0.24 & 0.01 & 0.40 \\
\hline Total & 24 & & & & & & \\
\hline Average & & 74.60 & 3.45 & 9.51 & 1.01 & 0.17 & 1.74 \\
\hline CV (\%) & & 26.58 & 26.38 & 26.50 & 62.20 & 73.25 & 69.42 \\
\hline
\end{tabular}

CV - Coefficient of variation; ${ }^{n s}$ Not significant; ${ }^{*}$ Significant at probability of $0.05(p<0,05)$ 
Magalhães et al. (2014) reported an increase in the stem diameter with lower cassava effluent doses, and a decrease with increased doses; for example, they observed a decrease at the dose of $63 \mathrm{~m}^{3} \mathrm{ha}^{-1}$. In addition, they reported an adverse effect on the absorption of other elements, such as calcium, magnesium, zinc, and manganese by the plant, if they are present in excess, possibly because of the high concentration of the potassium ion in the effluent (Malavolta et al., 1997).

Both the shoot dry biomass and biomass of grains (Figures $1 C$ and 1D) showed an increasing linear trend with the increased doses, especially with the higher doses. There was a great difference detected with the control treatment $\left(0.36 \mathrm{~g}\right.$ plant $\left.^{-1}\right)$ and with the highest dose of biofertilizer $\left(3.39 \mathrm{~g} \mathrm{plant}^{-1}\right)$ for the mass of the grains.

The increase in crambe biomass, with increasing biofertilizer doses, proves that this crop requires a high amount of nutrients and confirms the studies that state crambe as a good nutrient recycler (Pitol et al., 2010).

Barreto et al. (2014) observed that the use of increasing doses of cassava effluent on corn plants grown in sandy loam soil caused a positive linear increase in their dry biomass. Duarte et al. (2012) obtained a maximum plant dry biomass of $4.86 \mathrm{~g}_{\text {plant }}{ }^{-1}$ at a dose of $45 \mathrm{~m}^{3} \mathrm{ha}^{-1}$ of cassava effluent on lettuce.

Dantas et al. (2015) achieved the minimum (18.35 $\mathrm{g} \mathrm{plant}^{-1}$ ) and maximum (56.80 $\left.\mathrm{g} \mathrm{plant}^{-1}\right)$ accumulation of dry biomass in sunflower with the application of the smallest and largest doses of the cassava residue, respectively, which is in accordance with the results achieved in the this study. However, Santos et al. (2012) found no significant difference in dry biomass of crambe with the application of increasing doses of $\mathrm{K}_{2} \mathrm{O}$.

According to Prates et al. (2014) applying castor cake as a biofertilizer resulted in a positive linear increase in the biomass of crambe grains, with a maximum value of $1.56 \mathrm{~g} \mathrm{plant}^{-1}$ with the application of the highest dose of $8 \mathrm{t} \mathrm{ha}^{-1}$. This is close to the value reported by Pitol et al. (2010) (1.70 g of grain per plant). On the other hand, Santos et al. (2012) did not detect any increase in the grain mass with increasing doses of potassium, which was justified by the possible high potassium concentration in the soil.

The manipueira used in the present research was treated before its application to reduce its load of nutrients, such as potassium, magnesium, calcium, zinc, sodium, and iron. Because if the nutrient are in excess, they can be harmful to the plants, and reducing them along with the organic load of the residue favors the development of crambe (Barana \& Cereda, 2000).

The analysis showed that the oil content in the control treatment $\left(0 \mathrm{~kg} \mathrm{ha}^{-1}\right.$ of $\left.\mathrm{K}_{2} \mathrm{O}\right)$ was close to the one mentioned by the MS Foundation (2015), which is obtained through solvent extraction and ranges between 35 and 37\%. However, the values obtained with all treatments containing biofertilizer were lower than the ones obtained with the control treatment, and the smallest percentage was obtained with the largest dose of biofertilizer (Figure 2).

Potassium is extremely important to increase the oil concentration in grains because it plays an important role in the transport of photoassimilates; consequently, it is essential in oil synthesis and transport to the grains. In addition, potassium deficiency results in decreased productivity, oil content, and potassium concentration in the grains (Underwood, 1994).

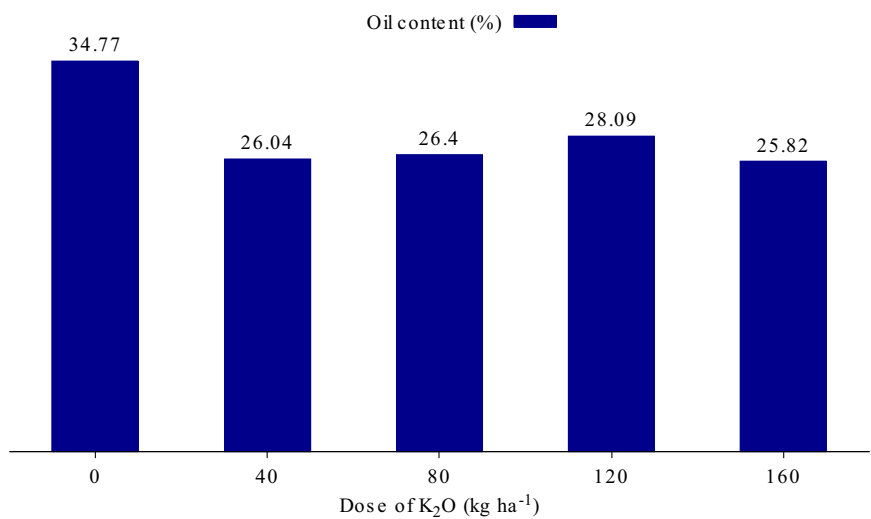

Figure 2. Mean values of oil content in crambe grains in relation to the application of biofertilizer doses $\left(\mathrm{kg} \mathrm{ha}^{-1}\right.$ of $\mathrm{K}_{2} \mathrm{O}$ )

However, in this study, there was no increase in the oil content due to the availability of potassium provided by the biofertilizer.

Similarly, Santos et al. $(2012 ; 2013)$ did not detect any effect of increasing the potassium doses $\left(0,15,30,60\right.$, and $90 \mathrm{~kg} \mathrm{ha}^{-1}$ of $\mathrm{K}_{2} \mathrm{O}$ ) on the oil content of crambe grains. However, Veiga et al. (2010) detected an increase in the oil content of soybeans with increasing doses of $\mathrm{K}_{2} \mathrm{O}$.

Under the conditions tested in this study, the biofertilizer obtained by anaerobic digestion of cassava effluent presented good results in the development of crambe plants. This biofertilizer associated with mineral fertilization can increase agricultural productivity, reduce fertilizer costs, and benefit the environment, because it is an efficient method for the disposal of cassava residue, which is generated on a large scale.

\section{Conclusions}

1. The highest applied dose of biofertilizer $\left(160 \mathrm{~kg} \mathrm{~K}_{2} \mathrm{O} \mathrm{ha}^{-1}\right)$ had the greatest effect on the development of crambe plants.

2. The oil content in crambe grains was lower in all the plants receiving treatments containing biofertilizer compared to the control treatment.

3. The biofertilizer obtained by anaerobic digestion of cassava effluent is a source of nutrients, and can be used as an alternative to regular fertilizers in crambe cultivation.

\section{Literature Cited}

Alves, J. M.; Leandro, W. M.; Alves, C. C. F.; Carlos, L.; Ribon, A. A.; Fernandes, K. L. Crambe dry matter and yield under doses of phosphorus and base saturation in the Cerrado of Goias. Revista Brasileira de Engenharia Agrícola e Ambiental, v.20, p.421-426, 2016. https://doi.org/10.1590/1807-1929/agriambi.v20n5p421-426 AOCS - American Oil Chemists Society. Official methods and recommended practices of the American Oil Chemists Society. 5.ed. Champaign: AOCS, 1998. 1200p.

APHA - American Public Health Association. Standard methods for the examination of water and wastewater. Washington: APHA, 1995. 2198p.

Barana, A. C.; Cereda, M. P. Cassava wastewater (manipueira) treatment using a two-phase anaerobic biodigestor. Revista Ciência e Tecnologia de Alimentos, v.20, p.183-186, 2000. https:// doi.org/10.1590/s0101-20612000000200010 
Barreto, M. T. L.; Magalhães, A. G.; Rolim, M. M.; Pedrosa, E. M. R.; Duarte, A. de S.; Tavares, U. E. Desenvolvimento e acúmulo de macronutrientes em plantas de milho biofertilizadas com manipueira. Revista Brasileira de Engenharia Agrícola e Ambiental, v.18, p.487-494, 2014. https://doi.org/10.1590/S141543662014000500004

Dantas, M. S. M.; Rolim, M. M.; Duarte, A. de S.; Pedrosa, E. M. R.; Tabosa, J. N.; Dantas, D. da C. Crescimento do girassol adubado com resíduo líquido do processamento de mandioca. Revista Brasileira de Engenharia Agrícola e Ambiental, v.19, p.350-357, 2015. https://doi.org/10.1590/1807-1929/agriambi.v19n4p350-357

Duarte, A. de S.; Silva, E. F. de F. e; Rolim, M. M.; Ferreira, R. F. de A. e L; Malheiros, S. M. M.; Albuquerque, F. da S. Uso de diferentes doses de manipueira na cultura de alface em substituição à adubação mineral. Revista Brasileira de Engenharia Agrícola e Ambiental, v.16, p.262-267, 2012. https://doi.org/10.1590/S141543662012000300005

EMBRAPA - Empresa Brasileira de Pesquisa Agropecuária. Centro Nacional de Pesquisa de Solos. Sistema brasileiro de classificação de solos. 2.ed. Rio de Janeiro: EMBRAPA, 2013. 306p.

Fageria, N. K. Nutrient interactions in crop plants. Journal of Plant Nutrition, v.24, p.1269-1290, 2001. https://doi.org/10.1081/PLN100106981

Feroldi, M. M.; Cremonez, P. A.; Feiden, A.; Rossi, E.; Nadaleti, W. C.; Antonelli, J. Cultivo do cambre: Potencial para produção de biodiesel. Revista Brasileira de Energias Renováveis, v.2, p.11-22, 2012.

Ferreira, D. F. Sisvar: Sistema de análise de variância. Versão 5.3. Lavras: UFLA, 2010.

Fundação MS. Fundação MS para Pesquisa e Difusão de Tecnologias Agropecuárias. Produtos: Crambe. Maracaju: Fundação MS, 2015. $3 p$.

Magalhães, A. G.; Rolim, M. M.; Duarte, A. de S.; Bezerra Neto, E.; Tabosa, J. N.; Pedrosa, E. M. R. Desenvolvimento inicial do milho submetido a adubação com manipueira. Revista Brasileira de Engenharia Agrícola e Ambiental, v.18, p.675-681, 2014. https:// doi.org/10.1590/S1415-43662014000700001

Malavolta, E.; Vitti, G. C.; Oliveira, S. A. Avaliação do estado nutricional de plantas: Princípios e aplicações. Piracicaba: Potafos, 1997. 308p.
Nakagawa, J. Testes de vigor baseados no desempenho das plântulas. In: Krzyzanoswki, F. C.; Vieira, R. D.; França Neto, J. B. (ed.). Vigor de sementes: Conceitos e testes. Londrina: ABRATES, 1999. Cap.3, p.2.1- 2.24.

Nobile, F. O.; Mussi, P. B. Variáveis biométricas de crambe (Crambe abyssinica) em função da aplicação de biofertilizante bovino. Nucleus, v.10, p.173-182, 2013. https://doi. org/10.3738/1982.2278.850

Pitol, C.; Broch, D. L.; Roscoe, R. Crambe: Tecnologia e produção. Maracaju: Fundação Mato Grosso, 2010.60p.

Prates, F. B. de S.; Genuncio, G. da C.; Ferrari, A. C.; Nascimento, E. C. do; Alvez, G. Z.; Palermo, D. P.; Zonta, E. Acúmulo de nutrientes e produtividade de crambe em função da fertilização com torta de mamona e serpentinito. Revista Ciência Rural, v.44, p.810-816, 2014. https://doi.org/10.1590/S0103-84782014000500008

Ribas, M. M. F.; Cereda, M. P.; Villas-Bôas, R. L. Use of cassava wastewater treated anaerobically with alkaline agents as fertilizer for maize (Zea mays L.). Brazilian Archives of Biology and Technology, v.53, p.55-62, 2010. https://doi.org/10.1590/S151689132010000100007

Santos, J. I. dos; Rogério, F.; Migliavacca, R. A.; Gouveia, B.; Silva, T. B. da; Barbosa, M. C. Efeito da adubação potássica na cultura do crambe. Bioscience Journal, v.28, p.346-350, 2012.

Santos, J. I. dos; Silva, T. R. B. da; Rogério, F.; Santos, R. F.; Secco, D. Yield response in crambe to potassium fertilizer. Industrial Crops and Products, v.43, p.297-300, 2013. https://doi.org/10.1016/j. indcrop.2012.07.043

Silva Júnior, J. J. da; Coelho, E. F.; Santa’Ana, J. A. do V.; Santana Júnior, E. B.; Pamponet, A. J. M. Uso da manipueira na bananeira 'Terra Maranhão' e seus efeitos no solo e na produtividade. Irriga, v.17, p.353-363, 2012.

Underwood, N. R. Potassium interactions and balanced plant nutrition. Better Crops with Food, v.77, p.26-27, 1994.

Veiga, A. D.; Pinho, E. V. de R. V.; Veiga, A. D.; Pereira, P. H. de A. R.; Oliveira, K. C. de; Pinho, R. C. von. Influência do potássio e da calagem na composição química, qualidade fisiológica e na atividade enzimática de sementes de soja. Revista Ciência e Agrotecnologia, v.34, p.953-960, 2010. https://doi.org/10.1590/ S1413-70542010000400022 